\title{
Perkembangan dan Corak Kegiatan Agroindustri Keripik Tempe di Kelurahan Purwantoro Kecamatan Blimbing
}

\author{
Marsela Rinielda Dua $^{{ }^{*},}$, Akhmad Faruq Hamdani ${ }^{1}$, Ika Meviana ${ }^{1}$ \\ Program Studi Pendidikan Geografi, Universitas Kanjuruhan Malang, Malang 65148, Indonesia \\ Email :*marselarini@gmail.com, a.faruqhamdani@unikama.ac.id, meviana@unikama.ac.id
}

Dikirim : 8 Juli 2020

Diterima: 25 September 2020

\begin{abstract}
Abstrak: Berdasarkan data UMKM Kota Malang, tempe menjadi salah satu sentra produk agroindustri yang berkembang di Kota Malang. Permasalahannya adalah Kota Malang tidak memiliki produksi tanaman pangan kedelai. Penelitian bertujuan untuk mengetahui perkembangan dan corak agroindustri, keterkaitan (interaksi) spasial dan kontribusi kegiatan agroindustri. Penelitian menggunakan metode deskriptif kuantitatif dengan menggunakan analisis deskriptif persentase dan tabulasi frekuensi. Tema analisis pendekatan keruangan yang digunakan yaitu analisis interaksi keruangan. Hasil dari perkembangan dan corak kegiatan agroindustri adalah potensi bahan baku kegiatan agroindustri menggunakan 28-321 lonjor perbulan, potensi jasa distribusi dan jasa perdagangan menyalurkan hasil produksinya dengan 2 alur, potensi infrastruktur transportasi menggunakan alat transportasi sepeda motor dan potensi instutusi permodalan yang digunakan Rp.17.250.000 - Rp.31.500.000 perbulan. Keterkaitan (interaksi) spasial kegiatan agroindustri adalah lokasi asal bahan baku agroindustri tempe berada di Kelurahan Purwantoro. Tempat produksi berada dilokasi yang sama dengan lokasi asal bahan baku di Kelurahan Purwantoro dan Kota Malang menjadi target utama tempat pemasaran. Kontribusi kegiatan agroindustri menciptakan tenaga kerja yang merekrut sebanyak 370 tenaga kerja dan kontribusi terhadap pendapatan rumah tangga Rp.250.000-Rp.400.000 perminggu serta keuntungan bagi pengusaha agroindustri tempe Rp.1.000.000 - Rp.6.750.000 perbulan.Penelitian diharapkan dapat menambah wawasan dan pengetahuan untuk perkembangan agroindustri tempe dan dapat dijadikan sebagai informasi dan referensi dalam penyusunan penelitian.
\end{abstract}

Kata kunci: agroindustri, keripik tempe

\begin{abstract}
Based on data UMKM in Malang, tempe is one of the centers of developing agroindustrial products in Malang. The problem is that Malang does not have soybean food crop production. The research aims to determine the development and patterns of agroindustry, spatial linkages and the contribution of agroindustry activities. The study used descriptive quantitative method using descriptive percentage analysis and frequency tabulation. The theme of spatial approach analysis used is spatial interaction analysis. The results of the development and pattern of agroindustry activities are the potential of raw materials for agroindustrial activities using 28-321 spikes per month, the potential of distribution services and trade services to channel their production products with 2 grooves, the potential of transportation infrastructure using motorcycle transportation equipment and the potential of capital institutions used Rp.17,250 .000 - Rp.31,500,000 per month. The spatial linkages (interaction) of agroindustry activities are the locations of origin of tempe agroindustry in Purwantoro Village. The production site is located in the same location as the origin of raw materials in Purwantoro Village and Malang City is the main target of the marketing place. The contribution of agroindustry activities creates a workforce that recruits as many as 370 workers and contributes to household income Rp.250,000Rp.400,000 per week and profits for tempe agroindustry entrepreneurs Rp.1,000,000 - Rp.6,750,000 per month. Research is expected to add insight and knowledge for the development of tempe agroindustry and can be used as information and references in the preparation of research.
\end{abstract}

Keywords: agroindustry, tempe chips 


\section{Pendahuluan}

Agroindustri merupakan penggerak utama perkembangan sektor pertanian, terlebih dalam masa yang akan datang posisi pertanian merupakan sektor andalan dalam pembangunan nasional sehingga peranan agroindustri akan semakin besar. Dalam upaya mewujudkan sektor pertanian yang tangguh, maju dan efisien sehingga mampu menjadi leading sector dalam pembangunan nasional, harus ditunjang melalui pengembangan agroindustri, menuju agroindustri yang tangguh, maju serta efisien. Menurut Tambunan (2003) pengembangan sektor agroindustri memilik beberapa sasaran yaitu, sebagai penggerak pembangunan sektor pertanian dengan menciptakan pasar permintaan input untuk produk olahannya, menciptakan lapangan kerja, meningkatkan nilai tambah, meningkatkan penerimaan devisa dan meningkatkan pemerataan pembagian pendapatan (Soekartawi, 2010).

Kota Malang merupakan salah satu potensi pertumbuhan industri dan perdagangan di Jawa Timur. Kota Malang sebagai salah satu kota di Jawa Timur memiliki perkembangan jumlah unit usaha yang relatif sangat baik. Kota Malang adalah daerah padat karya yang didominasi industri kecil dan menengah dengan sedikit industri manufaktur. Salah satu potensi yang cukup berkembang adalah semakin banyak pelaku ekonomi industri berbasis pertanian di Kota Malang. Berdasarkan pada data Disperindag Kota Malang (2014), Kota Malang memiliki tujuh sentra industri yang memiliki potensi untuk dikembangkan yaitu sentra saniter, sentra keramik, sentra rotan, sentra mabel, sentra kripik tempe, sentra marning jagung dan sentra gerabah.

Perkembangan agroindustri di Kota Malang sangat mengalami perlonjakan yang besar. Hal ini juga membuktikan bahwa usaha industri berbasis pertanian Kota Malang berkembang cukup signifikan dengan banyaknya kegiatan agroindustri yang dapat ditemui di kota Malang, tetapi yang menjadi persoalan adalah Kota Malang bukan merupakan daerah yang memiliki banyak potensi pertanian, sedangkan agroindustri tidak bisa terlepas dari hasil pertanian sebagai dasar penggerak utama kegiatan agroindustri.

Agroindustri tempe terdapat berbagai kegiatan yang mencakup gambaran perkembangan dan corak kegiatan agroindustri yaitu faktor potensi bahan baku, faktor sumber daya alam, faktor potensi fasilitas jasa distribusi dan jasa perdagangan, faktor potensi infrastruktur transportasi, faktor institusi permodalan dan faktor industri hilir. Kegiatan pengadaan bahan baku merupakan kegiatan yang sangat penting pada agroindustri, termasuk agroindutri tempe. Hal ini dikarenakan bahan baku merupakan faktor utama dalam pembuatan suatu produk dalam kegiatan agroindustri. Pemakaian bahan baku oleh agroindustri sangat erat kaitannya dengan produksi pertanian sebagai sumber bahan baku. Oleh karena itu, perhatian terhadap bahan baku merupakan hal yang sangat penting.

Keterkaitan keruangan (spasial) dari kegiatan agroindustri yang berkembang dapat dilihat dari lokasi asal bahan baku, tempat produksi dan daerah pemasaran. Dari lokasi bahan baku, tempat produksi dan daerah pemasaran tersebut akan dapat terlihat pola hubungan antar-daerah yang mencerminkan fungsi dari masing-masing daerah.

Selain itu juga sangat penting untuk mengetahui keterkaitan agroindustri dengan kesejahteraan masyarakat sekitar daerah kegiatan agroindustri yang dalam hal ini berkaitan dengan kontribusi apa saja yang bisa didapatkan dari keberadaan agroindustri, baik memberikan kesempatan kerja serta kontribusinya terhadap pendapatan rumah tangga.

Tujuan dari penelitian untuk mengetahui gambaran perkembangan dan corak agroindustri tempe di kecamatan Blimbing Kota Malang, mengetahui keterkaitan spasial kegiatan agroindustri tempe di Kecamatan Blimbing Kota Malang dan menganalisis kontribusi kegiatan agroindustri di Kecamatan Blimbing dalam hal penciptaan kesempatan kerja dan pendapatan rumah tangga. 


\section{Metode Penelitian}

Penelitian ini adalah penelitian deskriptif kuantitatif. Menurut Sugiyono (2009), penelitian deskriptif digunakan untuk mendeskripsikan atau menggambarkan data yang telah terkumpul sebagaimana adanya. Metode penelitian deskriptif kuantitatif adalah metode yang berlandaskan pada filsafat positivisme, digunakan untuk meneliti pada populasi atau sampel tertentu. Pengumpulan data menggunakan instrument penelitian, analisis data bersifat kuantitatif/statistik, dengan tujuan untuk menguji hipotesis yang telah ditetapkan (Sugiyono, 2012). Berdasarkan teori tersebut, penelitian deskriptif kuantitatif, merupakan data yang diperoleh dari sampel, populasi penelitian dianalisis sesuai dengan metode statistik yang digunakan variabel dalam penelitian ini adalah faktor perkembangan dan corak, keterkaitan (interaksi) spasial dan kontribusi kegiatan Agroindustri.

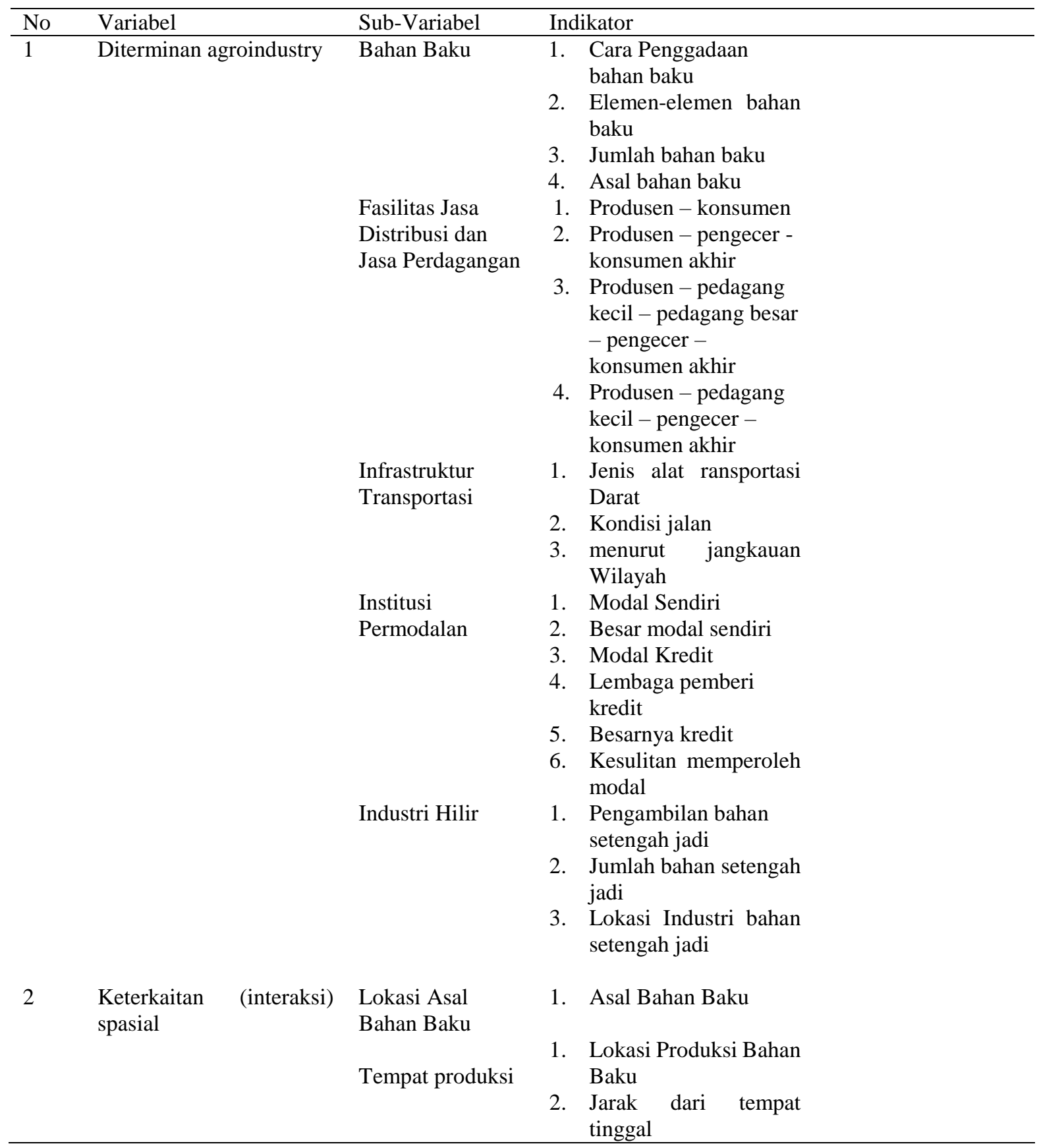




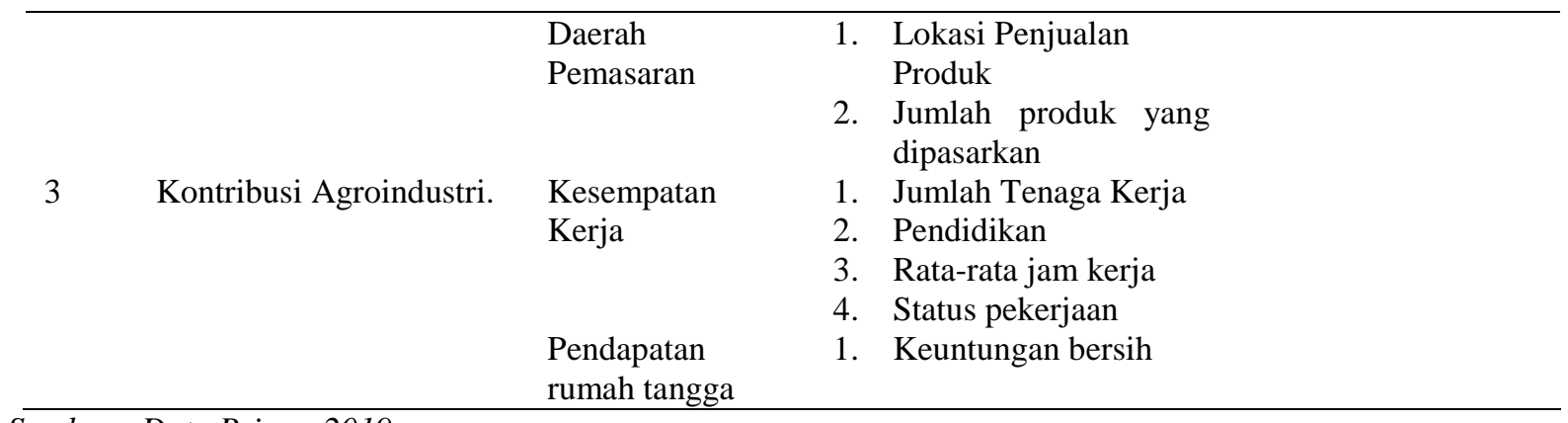

Sumber : Data Primer 2019

Alasan menggunakan metode ini agar dapat menjawab rumusan masalah skripsi ini dan dapat mendeskripsikan data berupa angka yang menjawab rumusan masalah.

\section{Pengumpulan data}

Teknik pengumpulan data menggunakan angket dan dokumentasi. Instrumen pengumpulan data adalah alat bantu yang dipilih dan digunakan oleh peneliti dalam kegiatannya mengumpulkan agar kegiatan tersebut menjadi sistematis dan dipermudah olehnya. Instrument penelitian yang digunakan dalam penelitian ini adalah angket. Teknik pengambilan sampel dalam penelitian ini adalah menggunakan teknik Probability sampling. Teknik sampling ini memberikan peluang yang sama bagi seluruh anggota populasi untuk dipilih menjadi anggota sampel. Simple random sampling merupakan teknik pengambilan sampel yang dilakukan secara acak tanpa memperhatikan strata yang ada dalam populasi tersebut. Cara ini hanya dapat dilakukan bila sifat anggota populasi memiliki sifat yang homogen atau memiliki karakter yang sama. Cara untuk menentukan responden menggunakan rumus slovin, adapun penelitian ini menggunakan rumus slovin karena dalam penarikan sampel jumlah harus representative agar hasil penelitian dapat digeneralisasikan dan hasilnya dapat diperhitungkan. Jumlah populasi dalam penelitian ini adalah sebanyak 393, sehingga presentasi kelonggaran yang di gunakan adalah $90 \%$ dan perhitungan dapat dibulatkan untuk mencapai kesusaian dengan hasil 80 responden.

\section{Analisis data}

Penelitian ini merupakan penelitian deskriptif kuantitatif, dengan menggunakan analisa deskriptif atau statstik deskriptif. Statistik deskriptif adalah statistik yang berfungsi untuk mendeskripsikan atau memberi gambaran terhadap obyek yang diteliti melalui data sampel atau populasi sebagaimana adanya, tampa melakukan analisis dan membuat kesimpulan yang berlaku untuk umum. (Sugiyono, 2003). Metode analisis data yang digunakan dalam penelitian ini adalah analisis deskriptif persentasi dan tabulasi frenkuensi. Analisis deskriptif persenatase digunakan untuk mengetahui angka atau jumlah utuk mengetahui hasil dari rumusan masalah dan tabulasi frekuensi adalah penyusunan data dalam bentuk kelompok mulai dari yang terkecil sampai yang terbesar berdasarkan kelas-kelas interval dan kategori tertentu. Manfaat penyajian data dalam bentuk Distribusi Frekuensi adalah untuk menyederhanakan penyajian data sehingga menjadi lebih mudah untuk dibaca dan dipahami sebagai bahan informasi. 


\section{Hasil Penelitian}

\section{Perkembangan dan corak kegiatan agroindustri tempe di kecamatan blimbing kota malang}

\section{Faktor potensi bahan baku}

Tabel 1. Jumlah Penggunaan Bahan Baku

\begin{tabular}{clcc}
\hline No & \multicolumn{1}{c}{ Jumlah Penggunaan } & EResponden & Persentase $(\%)$ \\
\hline 1 & 907-1200 Lonjor & 3 & 4 \\
2 & 614-907 Lonjor & 2 & 3 \\
3 & 321-614 Lonjor & 29 & 36 \\
4 & 28-321 Lonjor & 46 & 57 \\
\hline & Jumlah & 80 & 100 \\
\hline
\end{tabular}

Sumber : Data Primer 2019

Tabel diatas menunjukan sebanyak 4\% dengan jumlah 3 responden menggunakan 907 sampai 1200 lonjor perbulan, 3\% dengan jumlah 2 reponden menggunakan 614 samapai 907 Lonjor perbulan, 36\% dengan jumlah 29 responden menggunakan 321 sampai 614 lonjor perbulan dan $57 \%$ dengan jumlah responden terbanyak yaitu 46 responden menunjukan penggunaan tempe dalam satu bulan 28 sampai 321 Lonjor (1 Lonjor panjangnya 1 meter).

Tabel 2. Perolehan Bahan Baku

\begin{tabular}{clcc} 
No & Tempat Memperoleh Bahan Baku & Nesponden & Persentase (\%) \\
\hline 1 & Koperasi & 8 & 10 \\
2 & Perorangan & 72 & 90 \\
3 & Tidak Tentu (Kopersi atau & 0 & 0 \\
& Perorangan & & 100 \\
\hline \multicolumn{1}{c}{ Jumlah } & 80 & \\
\hline
\end{tabular}

Sumber : Data Primer 2019

Data pada tabel 2 menunjukan tempat memperoleh bahan baku 10\% dengan jumlah 8 responden memperoleh bahan baku dari koperasi dan $90 \%$ dengan jumlah 72 responden sebagai jumlah terbanyak mendapatkan bahan baku dari perorangan yang merupakan kenalan dari setiap responden. cara perolehan bahan baku biasanya diantar oleh pengrajin tempe, diambil sendiri ketempat bahan baku ataupun terkadang diantar dan diambil sendiri (tidak tentu). Sejumlah 44 responden dengan total 55\% memperoleh bahan baku diantar oleh pengrajin tempe ke pengrajin kerpik tempe, 26 responden dengan total 32,5\% mengambil sendiri ketempat bahan baku dan 10 responden dengan total 12,5\% tidak tentu (kadang diantar atau diambil sendiri).

\section{Faktor fasilitas jasa distribusi dan jasa perdagangan}

Tabel 3. Alur Penyaluran

\begin{tabular}{clcc}
\hline No & Alur Penyaluran & $\sum$ Responden & Persentase $(\%)$ \\
\hline 1 & $\begin{array}{l}\text { 1 Alur (Konsumen atau Pedagang Kecil } \\
\text { atau Toko) }\end{array}$ & 29 & 36,25 \\
2 & $\begin{array}{l}\text { 2 Alur (Konsumen dan Pedagang Kecil } \\
\text { atau Konsumen dan Toko atau Pedagang }\end{array}$ & 36 & 45 \\
$\begin{array}{l}\text { Kecil dan Toko ) } \\
3\end{array}$ & $\begin{array}{l}\text { 3 Alur (Konsumen, Pedagang Kecil dan } \\
\text { Toko) }\end{array}$ & 15 & 18,75 \\
\hline$\quad$ Jumlah & 80 & 100 \\
\hline
\end{tabular}

Sumber : Data Primer 2019 
Tabel 3 menunjukan alur penyaluran produksi agroindustri keripik tempe 1 alur penyaluran langsung ke konsumen atau pedagang kecil atau toko sebanyak 29 responden dengan total $36,25 \%, 2$ alur penyaluran sebanyak 36 responden dengan total $45 \%$ yang mana paling banyak alur penyalurannya, 3 alur sebanyak 15 responden dengan total 18,75\%. Proses pengiriman hasil produksi agroindustri keripik tempe diambil dari tempat produksi, diantar oleh pengrajin keripik tempe atau tidak tentu (terkadang diambil atau diantar). Sejumlah 27 responden dengan total $33,75 \%$ diambil oleh pemesan dari tempat produksi, 19 responden dengan total $23,75 \%$ diantar oleh pengraji keripik tempe dan 34 responden dengan total 42,5\% tidak tentu (terkadang diambil atau diantar).

\section{Faktor infrastruktur transportasi}

Tabel 4. Jenis Alat Tranportasi Pengiriman Hasil Produksi

\begin{tabular}{clcc}
\hline No & Jenis Alat Tranportasi & Responden & Persentase $(\%)$ \\
\hline 1 & Mobil & 27 & 33,73 \\
2 & Sepeda Motor & 67 & 83,75 \\
3 & Becak & 1 & 1,25 \\
4 & Truk ekspedisi & 5 & 6,25 \\
5 & Jasa Pengiriman Barang & 8 & 10 \\
\hline & Jumlah & 80 & 100 \\
\hline
\end{tabular}

Sumber : Data Primer 2019

Tabel 5.4 menunjukan 5 jenis alat transportasi yang digunakan untuk pengiriman hasil produksi keripik tempe. Setiap responden menggunakan satu atau lebih alat transportasi untuk mengirim hasil produksi. Alat transportasi yang paling banyak digunakan yaitu sepeda motor yaitu sebanyak 67 responden dengan total 83,75\% dikarenakan hasil produksi paling banyak di pasarkan di kota Malang mengingat jarak tempu yang tidak terlalu jauh. Selanjutnya alat transportasi yang digunakan yaitu mobil sebanyak 27 responden dengan total 33,73\%, Becak 1 responden dengan total $1,25 \%$, truk ekspedisi 5 rsponden dengan total $6,25 \%$ penggunaan, hal ini dikarenakan pengiriman hasil produksi ke luar pulau jawa. Penggunan jasa pengiriman barang sebanyak 8 responden dengan total $10 \%$, hal ini dikarenakan produsen maupun konsumen tidak bisa mengirimkan langsung ataupun mengambil langsung ketempat produksi sehingga menggunakan jasa pengiriman barang.

\section{Faktor institusi permodalan}

Tabel 5. Modal Usaha

\begin{tabular}{llcc}
\hline No & Nominal & Nesponden & Persentase $(\%)$ \\
\hline 1 & Rp.45.750.000 - Rp.60.000.000 & 6 & 7,5 \\
2 & Rp.31.500.000 - Rp.45.750.000 & 9 & 11,25 \\
3 & Rp.17.250.000 - Rp.31.500.000 & 36 & 45 \\
4 & Rp.3.000.000 - Rp.17.250.000 & 29 & 36,25 \\
\hline & Jumlah & 80 & 100 \\
\hline
\end{tabular}

Sumber : Data Primer 2019

Tabel 5.5 menunjukan dari 80 responden, sebanyak 7,5\% dengan jumlah 6 responden menggunakan modal sekitar Rp.45.750.000 - Rp.60.000.000 perbulan, 11,25\% dengan jumlah 9 rsponden menggunakan modal sekitar Rp.31.500.00 - Rp.45.750.00 perbulan, $45 \%$ dengan jumlah responden terbanyak yaitu 36 responden menggunakan modal sekitar Rp.17.250.000 Rp.31.500.000 perbulan dan 36,25\% dengan jumlah 29 responden menggunakan modal sekitar Rp.3.000.000 - Rp.17.250.000 perbulan. Sebanyak 71 responden dengan total 88,75\% 
menggunakan modal sendiri dikarenakan pengrajin agroindustri keripik tempe tidak ingin membebankan usahanya.

\section{Keterkaitan (Interaksi) Spasial Kegiatan Agroindustri Tempe di Kecamatan Blimbing}

Keterkaitan interaksi spasial kegiatan agroindustri yang berkembang dapat dilihat dari lokasi asal bahan baku, tempat produksi dan daerah pemasaran. Dari lokasi asal bahan baku, tempat produksi dan daerah pemasaran tersebut akan terlihat pola hubungan antar daerah yang mencerminkan fungsi dari masing-masing daerah.

\section{Lokasi Asal Bahan Baku}

Asal lokasi bahan baku tempe 100\% dengan jumlah 80 responden berasal dari Sanan kelurahan purwantoro kecamatan blimbing. Pengrajin keripik tempe tidak membeli bahan baku tempe keluar dari kelurahan purwantoro karena tempat produksi tempe berlokasi di sanan kelurahan purwantoro. Di kampung sanan kelurahan purwantoro pengrajin keripik tempe dan pengrajin tempe dibedakan. Pengrajin tempe umumnya membeli kedelai dari koperasi yang ada di kampung sanan, sedangkan kedelai dari koperasi sendiri diimpor dari luar negeri yaitu Amerika Serikat karena kedelai dari luar negeri dinilai lebih bagus dari segi kualitas yang bersifat kering sehingga mudah untuk difermentasi.

\section{Tempat Produksi}

Keterkaitan keruangan dalam kegiatan agroindustri juga dilihat dari lokasi produksi dari bahan baku. Lokasi produksi bahan baku agroindustri keripik tempe berada di lokasi yang sama dengan lokasi asal bahan baku. Total 100\% dengan jumlah 80 responden bahan baku tempe juga diproduksi di kampung sanan kelurahan purwantoro kecamatan blimbing. hal ini dikarenakan untuk mempermudah pengrajin keripik tempe, pengrajin tempe dan kopersi penyuplai kedelai untuk melakukan interaksi. Pengrajin tempe akan lebih mudah mengantarkan tempe ke pengrajin keripik tempe atau diambil langsung ketempat produksi tempe dikarenakan jarak yang dekat dan tidak membutuhkan biaya ataupun tenaga yang banyak. Pengrajin tempe juga lebih mudah mendapatkan kedelai dengan kualitas yang baik karena koperasi penyuplai kedelai juga berada di kampung sanan kelurahan purwantoro.

\section{Daerah Pemasaran}

Tabel 6. Daerah Pemasaran Hasil Produksi Keripik Tempe

\begin{tabular}{llcc}
\hline No & Daerah Pemasaran & M Responden & Persentase $(\%)$ \\
\hline 1 & Malang & 80 & 100 \\
2 & Surabaya & 29 & 36,25 \\
3 & Semarang & 4 & 5 \\
4 & Jakarta & 19 & 23,75 \\
5 & Batu & 7 & 8,75 \\
6 & Kalimantan & 8 & 10 \\
7 & Bali & 8 & 10 \\
8 & Kediri & 4 & 5 \\
9 & Mojokerto & 6 & 7,5 \\
10 & Blitar & 5 & 6,25 \\
11 & Sidoarjo & 5 & 6,25 \\
\hline
\end{tabular}

Sumber : Data Primer 2019

Tabel 6 menunjukan terdapat 11 kota yang menjadi daerah pemasaran hasil produksi agroindustri keripik tempe. Daerah pemasaran hasil produk terbesar adalah Kota Malang dengan total $100 \%$ dari 80 responden. Hal ini dikarenakan lokasi produksi agroindustri keripik 
tempe berada disalah satu kecamatan yang ada di Kota Malang. Kota Malang menjadi target utama tempat pemasaran semua responden Karen jarak yang dekat. Daerah selanjutnya yaitu Surabaya dengan total 36,25\% dari 29 responden dan Jakarta dengan total 23,73\% dari 19 responden. Penyaluran hasil produksi ke daerah pemasaran tergantung permintaa konsumen baik di Kota Malang maupun diluar kota Malang.

\section{Kontribusi Kegiatan Agroindustri Tempe di Kecamatan Blimbing}

\section{Menciptakan Kesempatan Kerja}

Tabel 7. Tenaga Kerja

\begin{tabular}{llcc}
\hline No & Tenaga Kerja & $\sum$ Responden & Persentase $(\%)$ \\
\hline 1 & Memiliki Tenaga Kerja & 70 & 87,5 \\
2 & Tidak Memiliki Tenaga Kerja & 10 & 12,5 \\
\hline & Jumlah & 80 & 100 \\
\hline
\end{tabular}

Tabel 7 menunjukan bahwa tidak semua agroindustri keripik tempe menggunakan tenaga kerja tetapi terdapat $87,5 \%$ dengan jumlah 73 responden dari 80 responden menggunakan tenaga kerja dan terdapat $12,5 \%$ dengan jumlah responden 7 responden dari 80 responden tidak menggunakan tenaga kerja, karena pengrajin menggunakan tenaga sendiri dalam mengelolah agroindutri keripik tempe termasuk agroindustri kecil yang tidak banyak menggunakan modal.

Tabel 8. Tingkat Pendidikan Tenaga Kerja

\begin{tabular}{clcc}
\hline No & Tingkat Pendidikan & $\sum$ Tenaga Kerja & Persentase $(\%)$ \\
\hline 1 & Perguruan Tinggi & 0 & 0 \\
2 & SMA & 279 & 75,40 \\
3 & SMP & 77 & 20,82 \\
4 & SD & 14 & 3,78 \\
\hline & Jumlah & 370 & 100 \\
\hline
\end{tabular}

Sumber : Data Primer 2019

Tabel 8 menjelaskan setiap responden memiliki jumlah tenaga kerja yang berbeda-beda. Total dari 80 responden terdapat 370 Tenaga kerja yang berbeda-beda tingkat pendidikannya. Tingkat Pendidikan tenaga kerja terbanyak yaitu lulusan SMA dengan jumlah 279 tenaga kerja dengan total 75,40\%, lulusan SMP dengan jumlah 77 tenaga kerja dengan total 20,82\%, lulusan SD dengan jumlah 14 tenaga kerja dengan total 3,78\% dan tidak terdapat lulusan perguruan tinggi dari tenaga kerja.

Tabel 9. Rata-rata Jam Kerja Perhari

\begin{tabular}{llcc}
\hline No & Rata-rata Jam Kerja & NResponden & Persentase $(\%)$ \\
\hline 1 & $4-5$ Jam & 6 & 7,5 \\
2 & $7-8$ Jam & 51 & 63,75 \\
3 & $9-10$ Jam & 10 & 12,5 \\
4 & $12-13$ Jam & 3 & 3,75 \\
5 & 0 & 10 & 12,5 \\
\hline & Jumlah & 80 & 100 \\
\hline
\end{tabular}

Sumber : Data Primer 2019

Data juga menjelaskan dengan keberadaan agroindustri keripik tempe membawa dampak positif dengan tidak membatasi latarbelakang tingkat Pendidikan tenaga kerja. Tingkat Pendidikan juga tidak mempengaruhi rata-rata jam kerja dari setiap tenaga kerja. Hal ini dapat dilihat dari tabel 5.9, rata-rata jam kerja perhari tiap tenaga kerja paling banyak 7-8 jam perhari, terdapat 51 responden dengan total $63,75 \%$. Jumlah jam kerja juga bisa berubah dan bertambah jika konsumen memesan hasil produk dari biasanya. 


\section{Kontribusi terhadap Pendapatan Rumah Tangga}

Tabel 10. Jumlah Gaji Tenaga Kerja Perminggu

\begin{tabular}{lccc}
\hline No & Nominal & $\sum$ Responden & Persentase $(\%)$ \\
\hline 1 & Rp.550.000 - Rp.700.000 & 7 & 8,75 \\
2 & Rp.400.000 - Rp.550.000 & 14 & 17,5 \\
3 & Rp.250.000 - Rp.400.000 & 39 & 48,75 \\
4 & Rp.100.000 - Rp.250.000 & 10 & 12,5 \\
5 & 0 & 10 & 12,5 \\
\hline & Jumlah & 80 & 100 \\
\hline
\end{tabular}

Sumber : Data Primer 2019

Data pada tabel 10 menunjukan gaji rata-rata tenaga kerja perminggu. Tenaga kerja dari 80 responden memiliki jumlah gaji yang berbeda-beda. Hal ini dikarenakan gaji yang diberikan pengrajin keripik tempe kepada tenaga kerja sesuai dengan banyak tidaknya hasil yang produksi. Data tabel 5.10 menunjukan terdapat 39 responden dengan total 48,75\% dengan ratarata gaji tenaga kerja berkisar antara Rp.250.000 - Rp.400.000 perminggu. Selain memberikan kontribusi bagi tenaga kerja, agroindustri keripik tempe juga memberikan kontribusi berupa keuntungan bagi pengusaha agroindustri keripik tempe.

Tabel 5.11. Jumlah Keuntungan Perbulan

\begin{tabular}{llcc}
\hline No & \multicolumn{1}{c}{ Nominal } & NResponden & Persentase $(\%)$ \\
\hline 1 & Rp.18.250.000 - Rp.24.000.000 & 2 & 2,5 \\
2 & Rp.12.500.000 - Rp.18.250.000 & 1 & 1,25 \\
3 & Rp.6.750.000 - Rp.12.500.000 & 33 & 41,25 \\
4 & Rp.1.000.000 - Rp.6.750.00 & 44 & 55 \\
\hline & Jumlah & 80 & 100 \\
\hline
\end{tabular}

Sumber : Data Primer 2019

Data pada tabel 5.11 menunjukan jumlah keuntungan setiap bulan yang diperoleh pengrajin keripik tempe. Keuntungan yang diperoleh setiap bulannya dari 80 responden berbeda-beda, tergantung besar kecilnya usaha dan modal yang dikeluarkannya. Data pada tabel menunjukan hanya terdapat 2 responden dengan total 2,5\% mendapatkan keuntungan Rp.18.250.00 Rp.24.000.000, hanya 1 responden dengan total 1,25\% mendapatkan keuntungan Rp.12.500.000 - Rp.18.250.00. Terdapat juga 33 responden mendapatkan keuntungan sekitar Rp.6.750.000 - Rp.12.500.000. Selain itu juga terdapat 44 responden yang mendapatkan keuntungan kecil sekitar Rp.1.000.000 - Rp.6.750.000 dan merupakan responden terbanyak yang mendapatkan keutungan pada kisaran itu. Hal ini karena besar atau kecilnya modal mempengaruhi keuntungan pengrajin keripik tempe.

\section{Pembahasan}

\section{Perkembangan dan Corak Kegiatan Agroindustri Tempe}

Menurut Andri Kurniawan (2008) perkembangan dan corak agroindustri sangat tergantung dari berbagai faktor mencakup faktor potensi bahan baku, faktor sumberdaya alam dan lingkungan, faktor potensi fasilitas jasa distribusi dan perdagangan, faktor potensi infrastruktur transportasi dan faktor institusi permodalan. Faktor determinan saling memiliki keterkaitan satu sama lain dalam pengembangan agroindustri tempe.

Berdasarkan faktor potensi bahan baku, pengadaan bahan baku dilakukan untuk menunjang pelaksanaan proses produksi yang ada didalam suatu agroindustri. Bahan baku yang akan digunakan dalam agroindustri akan sangat tergantung kepada banyaknya keperluan bahan baku untuk pelaksanaan proses produksi dalam periode tertentu. Bahan baku yang digunakan oleh 
pengrajin agroindustri tempe hanya menggunakan 28 - 321 lonjor ( 1 lonjor panjangnya 1 meter). Penggunaan bahan baku ini oleh pengrajin agroindustri keripik tempe merupakan penggunaan yang termasuk sedikit dibandingkan beberapa responden lainnya. Hal ini berkaitan dengan beberapa elemen - elemen pengadaan bahan baku menurut Assauri (1999) adalah Kuantitas yaitu jumlah bahan baku yang cukup perlu dipenuhi untuk menjamin berjalannya proses pengolahan sesuai dengan kapasitas dan untuk kepentingan pemenuhan kebutuhan pasar dan biaya, yaitu di dalam pengadaan bahan baku agroindustri menjadi faktor penentu biaya karena pada umumnya bahan baku agroindustri menyerap sebagian besar biaya industri. Penetapan kesepakatan harga ditentukan dengan memperhatikan prinsip saling menguntungkan.

Perolehan atau penggadaan bahan baku dalam kegiatan agroindustri tempe biasanya dengan memperoleh atau membeli bahan baku yang berasal dari perorangan. Menurut Assuari (1999) yaitu pengadaan bahan baku, yaitu pengadaan dari barang - barang berwujud yang digunakan dalam proses produksi yang dapat diperoleh dari sumber - sumber alam atau dibeli dari supplier yang menghasilkan bahan baku bagi perusahan, dalam hal ini pengrajin agroindustri keripik tempe memperoleh dari supplier perorangan. Produk hasil kegiatan agroindustri tentunya perlu sarana untuk memasarkan hasil dari kegiatan agroindustri. Pemasaran ini diperlukan agar kegiatan agroindustri semakin berkembang, oleh karena itu sangat diperlukan faktor potensi fasilitas jasa distribusi dan jasa perdagangan.

Fasilitas jasa distribusi dan perdagangan merupakan fungsi pelayanan terhadap permintaan akan proses produksi dan pemasaran agroindustri. Proses distribusi produk sampai kepada pemakai akhir dapat panjang atau pendek, sesuai dengan tujuan dan kebijakannya. Apabila rantai tataniaga panjang, berarti produk tersebut sebelum sampai pada konsumen melewati berbagai macam perantara. Sebaliknya, mata rantai yang pendek menandakan bahwa produk tersebut langsung didistribusikan kepada konsumen tanpa memakai perantara (Hasyim, 2012).

Hasil penelitian pada faktor potensi jasa distribusi dan perdagangan, menyalurkan hasil produksinya dengan 2 alur. Alur penyaluran 2 alur ini berarti pengrajin agroindustri keripik tempe mengirimkan kekonsumen dan pedagang kecil, konsumen dan toko, atau pedagang kecil dan toko. Hal ini berkaitan dengan teori Hasyim (2012) berkaitan dengan saluran tataniaga yang dapat digunakan dalam pendistribusian produk pertanian. Terdapat 2 saluran yang berkaitan dengan hasil penelitian yaitu produsen - konsumen, bentuk saluran distribusi yang paling pendek dari produsen ke konsumen, tanpa menggunakan perantara.

Produsen dapat menjual barang yang dihasilkan melalui pos atau langsung mendatangi rumah konsumen (dari rumah ke rumah). Oleh karena itu saluran ini disebut saluran distribusi langsung. Kedua saluran produsen - pengecer - konsumen akhir, seperti halnya dengan jenis saluran yang pertama (produsen-konsumen), saluran ini juga disebut sebagai saluran distribusi langsung. Disini pengecer langsung melakukan pembelian kepada produsen. Artinya semua tetap berasal dari produsen hanya yang membedakan produsen bisa mengantarkan atau menyalurkan kekonsumen dan hanya pedagang kecil atau konsumen dan langsung ketoko atau produsen tidak langsung kekonsumen melainkan langsung mengantarkan ke pedagang kecil dan toko, hanya menyalurkan ke 2 aluran saja. Penyaluran hasil produksi kegiatan agroindustri tempe memerlukan faktor potensi infrastruktur transportasi yang mendukung lancarnya kegiatan agroindustri.

Faktor potensi infrastruktur transportasi sebagai dasar untuk pembangunan ekonomi dan saranan transportasi masyarakat serta pertumbuhan pada sektor industri. Berdasarkan hasil penelitian kegiatan agroindustri menggunakan alat transportasi sepeda motor untuk menyalurkan hasil produksi keripik tempe dikarenakan hasil produksi paling banyak dipasarkan di Kota Malang mengingat jarak tempu yang dekat dengan tempat hasil produksi. Selain itu untuk diluar kota Malang juga biasanya dikirim tetapi yang jaraknya masih bisa di 
tempu menggunakan sepeda motor. Menurut Steenbrik (1974) transportasi didefenisiskan sebagai perpindahan orang dan atau barang dengan menggunakan kendaraan atau alat lain dari tempat ketempat yang terpisah secara geografis. Menurut jangkauan hirarki kewilayahan termasuk jangkauan lokal karena mode transportasinya dominan menggunakan sepeda motor yang dimana batas administrasinya Desa dan Kota. Selain beberapa faktor yang sudah dijelaskan, kegiatan agroindustri juga memerlukan faktor potensi institusi permodalan dalam melancarkan kegiatan agroindustri tempe.

Faktor potensi institusi permodalan juga sangat berperan penting dalam pelaksanaan kegiatan agroindustri. Hasil penelitian pada faktor potensi institusi permodalan menunjukan penggunaan modal pada kegiatan agroindustri tempe sekitar Rp.17.250.000 - Rp.31.500.000. Jumlah modal yang digunakan merupakan jumlah modal rata-rata yang dikeluarkan oleh pengrajin agroindustri keripik tempe. Modal yang digunakan pengrajin tempe adalah modal sendiri. Menurut Mardiyatmo (2008) mengatakan bahwa modal sendiri adalah modal yang diperoleh dari pemilik usaha sendiri. Modal sendiri terdiri dari tabungan, sumbangan, hibah, saudara dan lain sebagainya. Penggunaan modal sendiri oleh pengrajin agroindustri keripik tempe dikarenakan penrajin keripik tempe tidak ingin membebankan usahanya dan dikarenakan juga pengrajin keripik tempe takut tidak sanggup untuk membayar jika jatuh tempo.

\section{Keterkaitan (Interaksi) Spasial Kegiatan Agroindustri Tempe}

Keterkaitan interaksi keruangan (spasial) dari kegiatan agroindustri yang berkembang dapat dilihat dari lokasi asal bahan baku, tempat produksi dan daerah pemasaran. Keterkaitan ini akan dapat terlihat pola hubungan antar-daerah yang mencerminkan fungsi dari masing-masing daerah.

Faktor lokasi asal bahan baku keripik tempe yaitu tempe, berasal dari Sanan kelurahan Purwantoro Kecamatan Blimbing. Pengrajin keripik tempe tidak membeli bahan baku tempe keluar dari kelurahan purwantoro karena tempat produksi tempe berlokasi di sanan kelurahan purwantoro. Di kampung sanan kelurahan purwantoro pengrajin keripik tempe dan pengrajin tempe dibedakan. Pengrajin tempe umumnya membeli kedelai dari koperasi yang ada di kampung sanan, sedangkan kedelai dari koperasi sendiri diimpor dari luar negeri yaitu Amerika Serikat karena kedelai dari luar negeri dinilai lebih bagus dari segi kualitas yang bersifat kering sehingga mudah untuk difermentasi. Jika dilihat dari lokasi bahan baku keripik tempe yaitu tempe yang digunakan dalam proses produksi kegiatan agroindustri keripik tempe mempunyai keterkaitan interaksi antar atau dalam ruang karena produksi bahan baku tempe berada di daerah Sanan kelurahan Purwantoro kecamatan Blimbing.

Keterkaitan keruangan yang lebih laus dalam kegiatan agroindustri juga dilihat dari lokasi tempat produksi dari bahan baku. Keterkaitan keruangan dalam kegiatan agroindustri juga dilihat dari lokasi tempat produksi dari bahan baku. Lokasi tempat produksi bahan baku agroindustri keripik tempe berada di lokasi yang sama dengan lokasi asal bahan baku. Bahan baku tempe juga diproduksi di kampung sanan kelurahan purwantoro kecamatan blimbing. Hal ini dikarenakan untuk mempermudah pengrajin keripik tempe, pengrajin tempe dan kopersi penyuplai kedelai untuk melakukan interaksi.

Pengrajin tempe akan lebih mudah mengantarkan tempe ke pengrajin keripik tempe atau diambil langsung ketempat produksi tempe dikarenakan jarak yang dekat dan tidak membutuhkan biaya ataupun tenaga yang banyak. Pengrajin tempe juga lebih mudah mendapatkan kedelai dengan kualitas yang baik karena koperasi penyuplai kedelai juga berada di kampung sanan kelurahan purwantoro. Kedelai sendiri juga diimpor langsung dari Amerika Serikat karena memiliki kualitas yang baik dan kering sehingga mudah difermentasi sehingga menghasilkan tempe yang baik. Pengrajin keripik tempe, pengrajin tempe dan koperasi penyuplai kedelai memiliki interaksi satu sama lain dalam satu ruang. Hal ini bisa dilihat 
bagaimana hubungan antara lokasi asal bahan baku dan lokasi tempat produksi yang saling berkaitan dalam satu ruang yang sama.

Pemasaran merupakan inti dari kegiatan agroindustri. Produk agroindustri yang dihasilkan tidak hanya untuk konsumsi masyarakat setempat tetapi juga dipasarkan kedaerah lain. Jangkauan pemasaran produk tergantung dari skala produksi dan jenis produk yang dihasilkan jenis produk yang dihasilkan juga menentukan pula jangkauan pemasarannya. Daerah pemasaran agroindustri tempe terdapat 11 kota yang menjadi daerah pemasaran hasil produksi agroindustri keripik tempe. Daerah pemasaran terbesar adalah kota Malang, dikarenakan lokasi produksi agroindustri keripik tempe berada disalah satu kecamatan yang ada di Kota Malang. Kota Malang menjadi target utama tempat pemasaran semua responden Karen jarak yang dekat dan mudah untuk dijangkau mengingat juga keripik tempe merupakan produk makanan yang gampang rusak jika terlalu lama berada diperjalanan. Selain kota Malang daerah yang merupakan pengiriman yang lumayan banyak yaitu Surabaya dengan karena kota Surabaya masih berada di satu region wilayah yang sama. Produk agroindustri yang dihasilkan tidak hanya untuk konsumsi masyarakat setempat tetapi juga dipasarkan di daerah lain. Hal ini bisa dilihat bagaimana hubungan lokasi tempat produksi dan daerah pemasaran yang saling berinteraksi antar ruang.

\section{Kontribusi Kegiatan Agroindustri Tempe}

Kegiatan agroindustri memberikan dampak yang besar untuk menciptakan kesempatan kerja dan memberikan kontribusi terhadap pendapatan rumah tangga. Perluasan kesempatan kerja dibuktikan dengan adanya penyerapan tenaga kerja dalam kegiatan agroindustri. Perluasan kesempatan kerja ditandai dengan banyaknya tenaga kerja yang terserap dalam kegiatan agroindustri. Kegiatan agroindustri dalam proses produksinya memerlukan tenaga kerja tergantung dari besar kecilnya produk yang akan dihasilkan. Begitupula dengan kontribusi terhadap pendapat rumah tangga yang memberikan pendapatan bagi pekerja dan pengusaha agroindustri tergantung dari besar kecilnya produk yang dihasilkan dan dikerjakan.

Berdasarkan hasil penelitian terdapat berbagai jumlah kebutuhan tenaga kerja dan dari beberapa responden terdapat juga yang tidak menggunakan tenaga kerja karena dikerjakan sendiri oleh pengrajin keripik tempe. sebagian besar pengusaha agroindustri tempe menggunakan tenaga kerja untuk memperlancar kegiatan usaha agroindustri keripik tempe. Tenaga kerja dalam usaha agroindustri keripik tempe rata-rata lulusan SMA. Kegiatan agroindustri keripik tempe dalam merekrut tenaga kerja tidak melihat latarbelakang Pendidikan dari tenaga kerja karena dilihat hanya keahlian dalam mengiris, menggoreng dan membungkus keripik tempe. Hal ini juga berlaku bagi jam kerja perhari dari tenaga kerja yang rata- rata jam kerjanya 7-8 jam perhari, karena tidak melihat latarbelakang Pendidikan hal ini menjadikan kegiatan agroindustri menjadi kegiatan yang memperluas kesempatan kerja. Perluasan kesempatan kerja ditandai dengan banyaknya tenaga yang terserap dalam kegiatan agroindustri. Kegiatan agroindustri dalam proses produksinya memerlukan banyak tenaga kerja.

Kontribusi dari kegiatan agroindustri memberikan bukan hanya kesempatan kerja tetapi juga memberikan kontribusi terhadap peandapatan rumah tangga baik itu untuk tenaga kerja maupun untuk pengusaha kegiatan agroindustri keripik tempe. Hasil penelitian menunjukan tenaga kerja mendapatkan gaji tenaga kerja rata-rata Rp.250.000 - Rp.400.000 perminggu. Hal ini dikarenakan gaji yang diberikan pengrajin keripik tempe kepada tenaga kerja sesuai dengan banyak tidaknya hasil yang produksi. Selain memberikan kontribusi bagi tenaga kerja, agroindustri keripik tempe juga memberikan kontribusi berupa keuntungan bagi pengusaha agroindustri keripik tempe.Keuntungan dari pengusaha keripik tempe rata-rata Rp. 1.000.000-

Rp.6.750.00 perbulan. Keuntungan tergantung besar kecilnya usaha dan modal yang dikeluarkannya. 


\section{Kesimpulan}

Perkembangan dan corak yang mempengaruhi kegiatan agroindustri tempe adalah faktor potensi bahan baku dalam kegiatan agroindustri menggunakan 28-321 lonjor (1 lonjor 1 meter) perbulan, faktor potensi jasa distribusi dan jasa perdagangan menyalurkan hasil produksinya dengan 2 alur, faktor potensi infrastruktur transportasi menggunakan alat transportasi sepeda motor untuk menyalurkan hasil produksinya dan faktor potensi instutusi permodalan yang digunakan merupakan modal sendiri sekitar Rp.17.250.000 - Rp.31.500.000 perbulan. Keterkaitan (interaksi) spasial kegiatan agroindustri adalah lokasi asal bahan baku agroindustri tempe berada di kampung Sanan Kelurahan Purwantoro Kecamatan Blimbing, tempat produksi berada dilokasi yang sama dengan lokasi asal bahan baku di kampung Sanan Kelurahan Purwantoro Kecamatan Blimbing dan daerah pemasaran terbesar adalah Kota Malang. Kontribusi kegiatan agroindustri adalah menciptakan tenaga kerja dan memberikan kontribusi terhadap pendapatan rumah tangga bagi tenaga kerja dengan upah sekitar Rp.250.000 Rp.400.000 perminggu serta keuntungan bagi pengusaha agroindustri tempe sekitar Rp.1.000.000 - Rp.6.750.000 perbulan.

\section{Ucapan Terimakasih}

Terima kasih kepada Tuhan yang Maha Esa atas berkat dan perlindung serta terima kasih kepada Kelurahan Purwantoro Kecamatan Blimbing atas bantuan yang diberikan sehingga terselesaikannya jurnal ini.

\section{Daftar Rujukan}

Ahyari, Agus. 2003. Manajemen Bahan-Bahan: Efisiensi Persediaan Bahan. Yogyakarata. BPFE Yogyakarta

Dinas Koperasi dan Usaha Mikro Kota Malang. 2017. UMKM . Malang.

Dinas Perindustrian dan Perdagangan Kota Malang. 2014.

Dirjen Bina Pengolahan dan Pemasaran Hasil Pertanian Departemen Pertanian. 2012.

Hasyim, A.I. 2012. Tataniaga Pertanian. Diklat Kuliah. Fakultas Pertanian Universitas Lampung

Kota Malang Dalam Angka 2017. Dinas Koperasi dan Usaha Mikro Kota Malang.

Miro, Fidel. 2012. Pengantar Sistem Transportasi. Jakarta : Penerbit Erlangga.

Prianto, Wahyu Fajar. 2011. Pola Pengembangan Agroindustri Yang Berdaya Saing (Studi Kasus Kabupaten Malang. Kabupaten Malang

Rohmana, Roroh. Sujaya, Dedi, Herdiansah. \& Yuroh, Fitri. 2017. Analisis Agroindustri Tempe (Studi Kasus pada Seorang Perajin di Desa Cikembulan Kecamatan Sidahmulih Kabupaten Pangandaran), Fakultas Pertanian Universitas Galuh

Saragih, B. 2004. Agribisnis: Paradigma Baru Pembangunan Ekonomi, Kumpulan Pemikiran. PT Surveyor Indonesia dan Pusat Studi Pembangunan LP-IPB. Jakarta.

Sarwono, B. 2007. Membuat Tempe dan Oncom. Penebar Swadaya. Jakarta

Shafira, Fadila. 2017. Analisis Keragaan Agroindustri Tahu Kulit di Kelurahan Gunung Sulah Kecamatan Way Halim Kota Bandar Lampung, Lampung

Soekartawi. 2010. Agribisnis: Teori dan Aplikasinya. Jakarta

Sugiyono. 2012. Metode Penelitian Kuantitatif Kualitatif dan dan R\&D. Bandung : Alfabeta

Suhardjo. 2008. Geografi Pedesaan, Sebuah Antologi. Yogyakarta 